\title{
Hydrologic Impacts of Mechanical Seeding Treatments on Sagebrush Rangelands
}

\author{
Frederick B. Pierson, ${ }^{1}$ Wilbert H. Blackburn, ${ }^{2}$ and Steven S. Van Vactor ${ }^{3}$ \\ Authors are ${ }^{1}$ Research Hydrologist, United States Department of Agriculture (USDA), Agricultural Research Service (ARS), Northwest Watershed \\ Research Center, 800 Park Blvd, Plaza IV, Suite 105, Boise, ID 83712; ${ }^{2}$ Area Director, Northern Plains Area, USDA, ARS, Northern Plains Area, Fort \\ Collins, CO 80525; and ${ }^{3}$ Hydrologist, USDA, ARS, Northwest Watershed Research Center, Boise, ID 83712.
}

\begin{abstract}
In and around the Great Basin, United States, restoration of shrub steppe vegetation is needed where rangelands are transitioning to annual grasslands. Mechanical seedbed preparation can aid native species recovery by reducing annual grass competition. This study was designed to investigate the nature and persistence of hydrologic and erosion impacts caused by different mechanical rangeland seeding treatments and to identify interactions between such impacts and related soil and vegetation properties. A cheatgrass (Bromus tectorum L.)-dominated site was burned and seeded with native grasses and shrubs in the fall of the year. An Amazon-drill and a disk-chain seeder were used to provide varying levels of surface soil disturbance. An undisturbed broadcast seeding was used as a control. Simulated rainfall was applied to 6 large $\left(32.5-\mathrm{m}^{2}\right)$ plots per treatment over 3 growing seasons at a rate of $63.5 \mathrm{~mm} \cdot \mathrm{h}^{-1}$. Rainfall was applied for 60 minutes under dry antecedent moisture conditions and for 30 minutes, 24 hours later under wet antecedent moisture conditions. The disk-chain created the largest reduction in infiltration and increase in sediment yield, which lasted for 3 growing seasons posttreatment. The Amazon-drill had a lesser impact, which was insignificant after the second growing season posttreatment. Surface soil properties showed little correlation with treatment-induced hydrologic and erosion impacts. Hydrologic recovery was strongly correlated with litter dynamics. The seeding treatments were unsuccessful at establishing seeded plant species, and the site once again became dominated by cheatgrass. A continuous upward trend in biomass production and surface litter cover was observed for all treatments between the beginning and end of the study because of cheatgrass invasion. Although the initial goal of using mechanical seeding treatments to enhance recovery of native grass species failed, cheatgrass production provided sufficient biomass to rapidly replenish surface litter cover necessary for rapid hydrologic stability of the site.
\end{abstract}

\section{Resumen}

Adentro y alrededor de la Gran Cuenca, Estados Unidos, se necesita la restauración de la vegetación de estepa arbustiva, donde los pastizales son una transición a zacatales anuales. La preparación mecánica de la cama de siembra puede ayudar a la recuperación de las especies nativas al reducir la competencia de zacates anuales. Este estudio se diseño para investigar la naturaleza y persistencia de los impactos hidrológicos y de erosión causados por diferentes tratamientos mecánicos de siembra de pastizales y para identificar interacciones entre tales impactos y las propiedades relacionadas del suelo y vegetación. Un sitio dominado por "Cheatgrass" (Bromus tectorum L.) fue quemado y sembrado con zacates nativos y arbustos en el otoño. Se usaron una sembradora amazona y una de cadena y discos para crear diferentes niveles de disturbio en la superficie del suelo. Una siembra al voleo en un sitio sin disturbio se usó como control. Se aplicó lluvia simulada, a una tasa de $63.5 \mathrm{~mm} \cdot \mathrm{h}^{-1}$, en seis parcelas grandes por tratamiento a lo largo de tres estaciones de crecimiento. La lluvia se aplicó por 60 minutos bajo condiciones secas del suelo y por 30 minutos bajo condiciones húmedas del suelo. La sembradora de cadena y disco produjo la mayor reducción en la infiltración y aumentó la producción de sedimentos, efecto que duró las tres estaciones de crecimiento posteriores a la aplicación de los tratamientos. La sembradora amazona tuvo un impacto menor, el cual fue insignificante después de la segunda estación de crecimiento posterior a la aplicación del tratamiento. Las propiedades de la superficie del suelo mostraron una baja correlación con los impactos hidrológicos y de erosión inducidos por los tratamientos. La recuperación hidrológica estuvo altamente correlacionada con la dinámica del mantillo. Los tratamientos de siembra no fueron exitosos para el establecimiento de plantas de las especies usadas, y el sitio fue dominado nuevamente por el "Cheatgrass." Se observó una tendencia ascendente continua en la producción de biomasas y la cobertura de mantillo de la superficie en todos los tratamientos entre el inicio y fin del estudio, a consecuencia de la invasión del "Cheatgrass." Mientras que la meta inicial de usar tratamientos de siembra mecánica para mejorar la recuperación de las especies nativas fracasó, la producción del "Cheatgrass" suministró suficiente biomasa para reponer rápidamente la cobertura de mantillo de la superficie del suelo necesaria para una rápida estabilidad hidrológica del sitio.

Key Words: cheatgrass, disk-chain, erosion, hydrology, infiltration, rangeland drill

\section{INTRODUCTION}

In the Great Basin and on the Snake River Plain, United States, restoration of shrub-steppe vegetation is needed where large

Correspondence: Dr Frederick B. Pierson, Research Hydrologist, USDA Agricultural Research Service, Northwest Watershed Research Center, 800 Park Blvd, Plaza IV, Suite 105, Boise, ID 83712. Email: fpierson@nwrc.ars.usda.gov

Manuscript received 4 February 2007; manuscript accepted 1 September 2007. acreages of rangeland are transitioning to cheatgrass (Bromus tectorum L.) monocultures (Young and Evans 1978; Billings 1990; USDI-BLM 1999). Cheatgrass increases fire size and frequency creating conditions that maintain annual grass dominance and prevent recovery of native species (Young and Evans 1978; Whisenant 1990; Billings 1994; Knick and Rotenberry 1997). On sites where cheatgrass has become dominant, mechanical seeding can aid in successful establishment of desirable species by enhancing seedbed conditions and 
reducing annual grass competition (Hull and Stewart 1948; Evans and Young 1978; Mattise and Scholten 1994; Ott et al. 2003). Establishment of stable native plant communities enhances ecological integrity, biological diversity, and overall rangeland health (National Research Council 1994; Masters and Sheley 2001; McIver and Starr 2001). Perennial vegetation can also provide greenstrips of fire-resistant vegetation that act as fuel breaks (Pellant 1994).

Mechanical seeding treatments can affect both the hydrologic and erosion condition of a site by altering surface soil and vegetation characteristics (Gifford 1975). The magnitude and duration of impact of a mechanical treatment is directly proportional to the degree the treatment disrupts critical soil and vegetation properties (Gifford and Skau 1967; Brown et al. 1985). Mechanical treatments, such as plowing and drilling, can positively influence the process of infiltration by changes in soil properties, such as bulk density, soil structure, and macroporosity (Blackburn 1983; Hutten and Gifford 1988). However, such treatments have also been shown to reduce infiltration rates and increase runoff on sagebrush rangeland because of surface sealing of bare soil exposed to raindrop impact (Gifford and Skau 1967; Tromble 1976; Gifford 1982; Brown et al. 1985). Surface runoff is influenced by disruption of surface drainage patterns; increases in detention storage caused by furrows, dikes, and dams created by the implement; and increased surface roughness (Tromble 1976; Brown et al. 1985; Hutten and Gifford 1988; Clary 1989). The susceptibility of the site to erosion can be altered by changes in soil erodibility and loss of vegetal cover to protect the soil surface from splash erosion by raindrop impact (Brown et al. 1985; Hutten and Gifford 1988). Maintenance of vegetation cover, soil organic matter, and surface litter all reduce the proportion of bare soil impacted by rainfall and can help reduce the negative hydrologic impacts of mechanical treatments (Gifford and Skau 1967; Blackburn and Skau 1974; Blackburn 1983; Brown et al. 1985; Hutten and Gifford 1988).

To control cheatgrass and establish a stable perennial plant community by mechanical means requires intensive site preparation (burying of cheatgrass seed) and accurate control of seeding depth (Evans and Young 1984). This study was designed to compare the hydrologic and erosion impacts of improved site preparation and seeding technologies being used to seed perennial plant species into cheatgrass infested rangelands. Specific study objectives were to 1) determine the magnitude of impact that different seedbed preparation and seeding treatments have on runoff and erosion, 2) quantify how long such impacts may persist after treatment, and 3) examine the relationship between soil and vegetation properties and mechanical seeding treatment-induced hydrologic and erosion responses.

\section{MATERIALS AND METHODS}

The study was conducted approximately $13 \mathrm{~km}$ northwest of Mountain Home, Idaho (lat $43^{\circ} 12^{\prime} \mathrm{N}$, long $115^{\circ} 48^{\prime} \mathrm{W}$, T2S R5E NW $1 / 4$ S36). Elevation of the site is $907 \mathrm{~m}$. Annual precipitation (1961-1990) averages $280 \mathrm{~mm} \cdot \mathrm{y}^{-1}$ (Owenby and Ezell 1992). Average minimum and maximum air temperature ranges from $-7.3^{\circ}$ and $2.8^{\circ} \mathrm{C}$ in January to $13.3^{\circ}$ and $33.3^{\circ} \mathrm{C}$ in July (Owenby and Ezell 1992). Soils are mapped as Chilcott silt loam, $0 \%-4 \%$ slopes, moderately deep and well-drained, and classified as fine, smectitic, mesic Abruptic Xeric Argidurids (Noe 1991; USDA-NRCS 2007). These soils formed in loess and alluvium derived from a variety of rocks and occur on basalt and alluvial plains and fan terraces. A duripan typically occurs between 51 and $102 \mathrm{~cm}$. The range site is loamy with a $20-25-\mathrm{cm}$ precipitation zone (Noe 1991). Vegetation is dominated by cheatgrass. Historic vegetation at the site consisted primarily of Wyoming big sagebrush (Artemisia tridentata subsp. wyomingensis Beetle \& Young) and thurber needlegrass (Stipa thurberiana Piper) with smaller amounts of sandberg bluegrass (Poa sandbergii Vasey), bottlebrush squirreltail (Sitanion hystrix [Nutt.] J.G. Smith), and rabbitbrush (Chrysothamnus nauseosus L.). The predominant land use has been domestic livestock grazing.

The entire study site was burned to improve cheatgrass control, fenced to exclude livestock, and seeded with a mixture of crested wheatgrass (Agropyron cristatum [L.] Gaertn.; $\left.4.5 \mathrm{~kg} \cdot \mathrm{ha}^{-1}\right)$ and Wyoming big sagebrush $\left(0.17 \mathrm{~kg} \cdot \mathrm{ha}^{-1}\right)$ in November 1989. An Amazon MT375 No-Till drill (Canadian Ministers of Agriculture 1985) and a disk-chain seeder consisting of a disk-chain, a land-imprinting roller bar, and seeder boxes (Pellant 1990; Wiedemann and Cross 1985, 2000) were used to provide varying levels of surface soil disturbance. The Amazon drill uses minimum tillage and seeds in a narrow furrow at a depth of approximately $1 \mathrm{~cm}$, immediately followed by a packer roller. Typical rangeland drills till with disks and seed at furrow depths from 5 to $15 \mathrm{~cm}$ depending on the application. The disk-chain method tills with disks and the imprinting roller bar while broadcast seeding in front of the imprinting bar. An undisturbed broadcast seeding was used as a third treatment to provide an experimental control. All treatments were applied as individual strips $15 \mathrm{~m}$ wide and $150 \mathrm{~m}$ long. Treatments were established in a randomized complete-block experimental design consisting of 3 blocks.

Simulated rainfall was applied to plots $3.05 \mathrm{~m}$ wide and $10.67 \mathrm{~m}$ long using a rotating-boom rainfall simulator (Swanson 1965) in June 1990, 1991, and 1992. The long axis of each plot was perpendicular to the predominant $2 \%$ slope determined by surveying. Plots were installed using sheet-metal flashing inserted into a narrow trench that was back-filled and compacted. The plot headwall extended from the soil surface to a depth of $25 \mathrm{~cm}$. Plot installation was done at least 1 month before conducting the rainfall simulation to allow the plot borders and headwall to form a good seal to the soil and allow any loose soil to reconsolidate.

Rainfall was applied simultaneously to a pair of plots within a treatment at a rate of $63.5 \mathrm{~mm} \cdot \mathrm{h}^{-1}$. Two simulator runs were conducted on each plot pair. An initial run at antecedent soil moisture that lasted at least 1 hour or until equilibrium runoff was observed (dry run) and a run 24 hours after the initial run, which lasted at least 0.5 hours or until equilibrium runoff was observed (wet run). Runoff was continuously measured using a bubbler gage attached to a small drop-box weir (Bonta and Goyal 2001). Break-point runoff hydrographs were digitized from strip-chart records produced by the bubbler gages. Runoff level was converted to flow rate using a calibration equation determined for each weir. Trapezoidal integration was used to calculate total runoff. Total rainfall 
was determined from the average of 6 plastic depth gauges placed on a uniform grid within each plot. Total infiltration was calculated as the difference between total rainfall and total runoff. Instantaneous infiltration rate was calculated as the difference between the time-averaged rainfall rate and the observed runoff rate. Final equilibrium infiltration rate was taken from the last measured value before simulated rainfall stopped.

Suspended sediment samples were taken at 2-minute intervals beginning when the runoff level reached $3 \mathrm{~mm}$ and lasting until steady-state runoff was observed. Thereafter, a 4-minute sampling interval was used. Additional suspended sediment samples were taken beginning 1 minute after simulated rainfall stopped and continuing at 1-minute intervals until the runoff level dropped below $3 \mathrm{~mm}$. Suspended-sediment samples were filtered for sand, silt, and clay particles $(45-\mu \mathrm{m}$ filter), dried at $105^{\circ} \mathrm{C}$ for 24 hours, weighed, and converted to sediment yield $\left(\mathrm{kg} \cdot \mathrm{ha}^{-1}\right)$ using the measured area and runoff volume of each plot. Sediment yield:runoff ratio and runoff:rainfall ratio were obtained by division.

Bulk soil samples were collected adjacent to each plot before the dry run for determination of particle size by the hydrometer method (Gee and Bauder 1986) and before the dry run and after the wet run for the determination of aggregate stability by the vapor-wetting, wet-sieve method with correction for sand (Kemper and Rosenau 1986). Open-ended core samples from the 0 - to $30-\mathrm{mm}$ depth were collected adjacent to each plot before the dry run for determination of organic carbon, the Walkley-Black procedure (Nelson and Sommers 1982), and below-ground root biomass. Root-biomass samples were rinsed with water, and all roots were collected, dried at $105^{\circ} \mathrm{C}$ for 24 hours, and weighed, then ashed in a muffle furnace at $610^{\circ} \mathrm{C}$ for 4 hours and weighed to determine ash-free belowground root biomass $\left(\mathrm{kg} \cdot \mathrm{m}^{-3}\right)$. Soil bulk density and gravimetric water content were determined from open-ended core samples from the 0 - to $30-\mathrm{mm}$ depth collected adjacent to each plot before both the dry and wet runs.

Following the wet run, all litter was collected, and all forbs and grasses were clipped at ground level within 5 randomly located $30.5-\mathrm{cm}^{2}$ subplots. The samples were dried at $60^{\circ} \mathrm{C}$ for 48 hours, weighed, and converted to aboveground biomass $\left(\mathrm{kg} \cdot \mathrm{ha}^{-1}\right)$. Point-frame frequency measures were conducted on each plot before rainfall simulation. Ten evenly spaced transects of 60 points each were sampled within each plot. The species of each canopy hit, ground-cover species or category, and relative ground-surface height were recorded for each point. Species cover was determined from the frequency of hits divided by the total number of points sampled within the plot. Relative ground-surface height at each point was calculated as the distance between the point-frame level line and the ground surface at the respective point. Soil surface random roughness was estimated as the arithmetic average of the standard deviations of the ground surface height for each of the 10 transects sampled within each plot.

The experimental design was a randomized complete block with 3 blocks and 3 treatments. Treatments were Amazon-drill, disk-chain, and control. Treatment effects on response variables were compared using a 1-way analysis of variance (ANOVA). All statistical analyses were performed using the SAS software (SAS 2001). Data were tested for normality and,

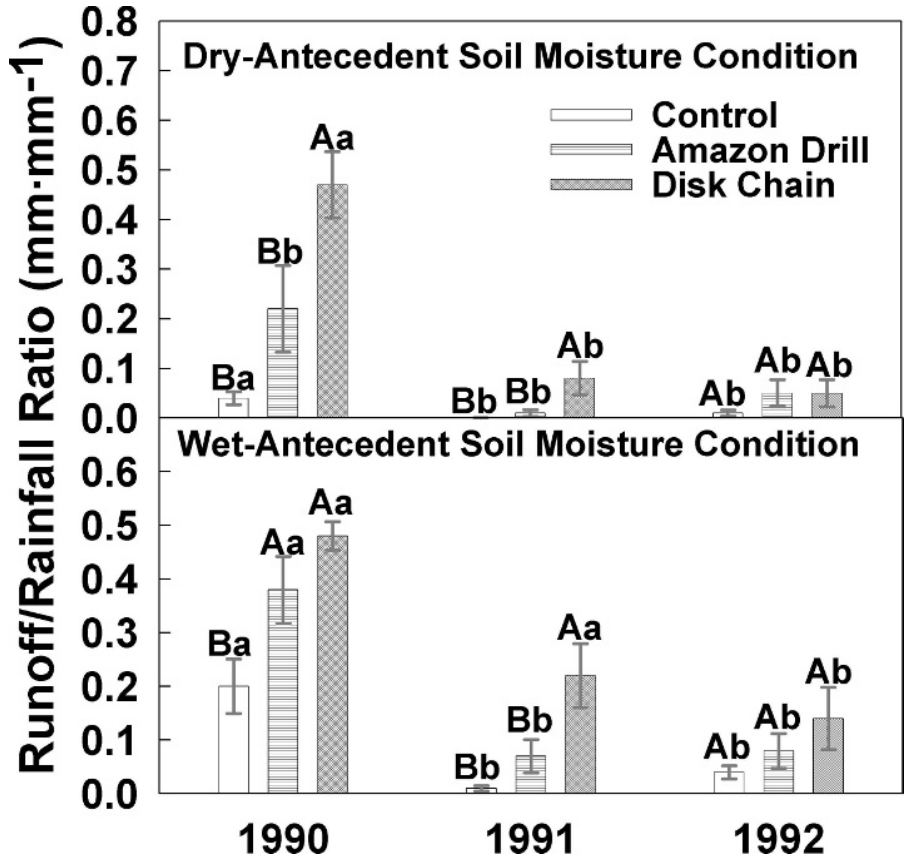

Figure 1. Cumulative runoff to cumulative rainfall ratios $\left(\mathrm{mm} \cdot \mathrm{mm}^{-1}\right)$ with standard error bars for both dry and wet antecedent soil moisture conditions. Uppercase letters indicate significant $(P \leq 0.05)$ differences between treatments within years, and lowercase letters indicate significant $(P \leq 0.05)$ differences between years within treatments. Sample size is 6 for all means presented.

if necessary, transformations performed to stabilize variances. Back-transformed means are reported. Statistical significance of all tests was set at $P<0.05$, and mean separations were conducted using Student-Newman-Keuls test.

\section{RESULTS}

The disk-chain and Amazon-drill treatments had significant effects on infiltration and runoff. The first summer following application, the Amazon-drill and disk-chain treatments had significantly greater runoff:rainfall ratios compared with the control (Fig. 1). The runoff:rainfall ratio for the disk-chain treatment was still significantly greater than the control the second summer following treatment, whereas the Amazon-drill treatment effect was no longer significantly different from the control. Both treatments were still slightly greater than the control the third summer, but the differences were not significant. Final infiltration rates showed similar results, although significant differences remained between the diskchain treatment and the control under wet-moisture conditions at the end of the study (Fig. 2).

Sediment yield was greater for the disk-chain than the control through 2 summers but decreased to control levels by the third summer following treatment (Table 1). During the first summer after treatment, cumulative sediment yield was significantly greater for the disk-chain treatment than the control for both the dry and wet antecedent moisture conditions (Table 1). The same trend was found for the second summer after treatment, but the average sediment yields for the disk-chain and the control were significantly smaller. Sediment 


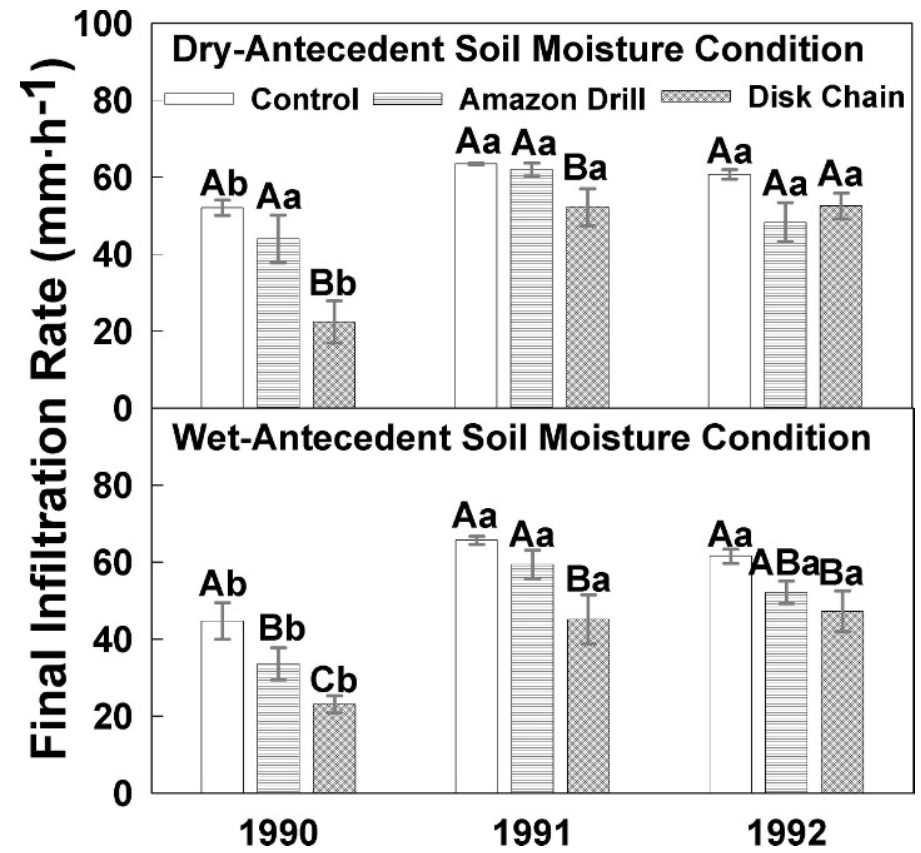

Figure 2. Final infiltration rates $\left(\mathrm{mm} \cdot \mathrm{h}^{-1}\right)$ with standard error bars for both dry and wet antecedent soil moisture conditions. Uppercase letters indicate significant $(P \leq 0.05)$ differences between treatments within years, and lowercase letters indicate significant $(P \leq 0.05)$ differences between years within treatments. Sample size is 6 for all means presented.

yield from the Amazon-drill treatment was significantly less than from the disk-chain the second summer. No significant differences in sediment yields were found between all treatments by the third summer. No statistical differences were found between the Amazon-drill treatment and the control throughout the study. The trends for sediment yield:runoff ratio were similar to those for total sediment yield for all treatments with one exception. Soil erodibility in the disk-chain treatment remained quite high into the second summer following treatment and then dropped during the third summer (Fig. 3).

Soil moisture was generally unchanged by seeding treatments under dry antecedent conditions but was decreased by the diskchain applications under wet antecedent conditions through 2 summers posttreatment (Table 2). Soil moisture was significantly higher for all treatments during the third sampling following treatment. Bulk density measured under dry antecedent moisture conditions was not significantly different between treatments until the third summer sampling, when the disk-chain treatment had significantly lower bulk density

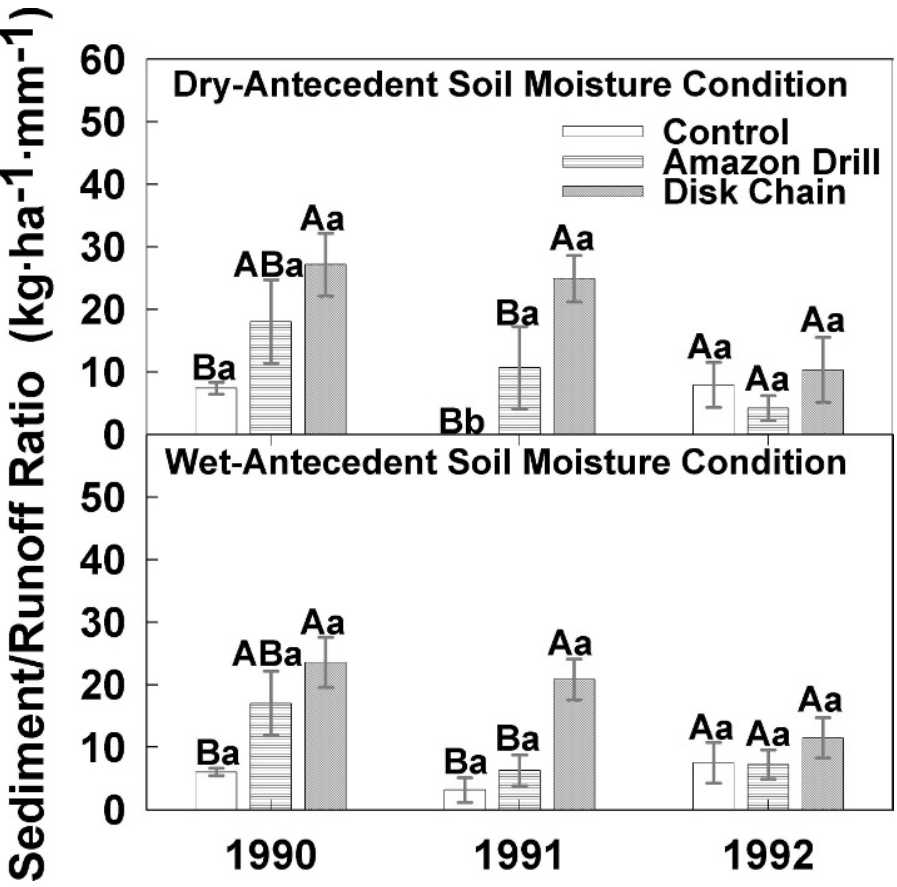

Figure 3. Cumulative sediment yield to cumulative runoff ratios $\left(\mathrm{kg} \cdot \mathrm{ha}^{-1} \cdot \mathrm{mm}^{-1}\right)$ with standard error bars for both dry and wet antecedent soil moisture conditions. Uppercase letters indicate significant $(P \leq 0.05)$ differences between treatments within years, and lowercase letters indicate significant $(P \leq 0.05)$ differences between years within treatments. Sample size is 6 for all means presented.

than the Amazon-drill treatment and the control (Table 2). The magnitude of the difference was small and likely due to natural variability or variability in sampling. Bulk density under wet antecedent moisture conditions was lower on disk-chain than on the control and Amazon-drill treatments 2 and 3 summers posttreatment and increased on the control and Amazon-drill sites 3 summers posttreatment.

Aggregate stability showed significant variations between treatments within a year and within a treatment between years (Table 2). Differences in aggregate stability under dry antecedent conditions were generally small between the control and the other treatments during the first 2 seasons. All treatments including the control showed significant decreases in aggregate stability during the third summer after treatment likely due to increased soil moisture content. Under wet antecedent conditions, aggregate stability was generally highest for the diskchain treatment because of mixing of the topsoil with more stable subsurface soil during disking. Wet aggregate stability did not show the large drop that was observed for dry aggregate stability during the third sampling after treatment.

Table 1. Cumulative sediment yields $\left(\mathrm{kg} \cdot \mathrm{ha}^{-1}\right)$ for each treatment by antecedent moisture content and year. Values presented are means (SD). ${ }^{1}$

\begin{tabular}{|c|c|c|c|c|c|c|}
\hline \multirow[b]{2}{*}{ Treatment } & \multicolumn{3}{|c|}{ Dry run } & \multicolumn{3}{|c|}{ Wet run } \\
\hline & 1990 & 1991 & 1992 & 1990 & 1991 & 1992 \\
\hline Amazon-drill & 273.2 ABa (329.5) & $10.7 \mathrm{Ba}(19.6)$ & $19.8 \mathrm{Aa}(23.1)$ & 175.8 ABa (142.6) & 18.1 Bb (23.2) & $27.8 \mathrm{Ab}(36.5)$ \\
\hline Disk-chain & $697.8 \mathrm{Aa}(482.3)$ & 145.1 Ab (160.4) & 84.4 Ab (140.9) & $332.0 \mathrm{Aa}(189.7)$ & 135.3 Ab (94.5) & $85.3 \mathrm{Ab}(87.6)$ \\
\hline Control & $21.4 \mathrm{Ba}(19.8)$ & $0.0 \mathrm{Bb}(0.0)$ & 10.3 Aab (11.6) & $33.0 \mathrm{Ba}(22.1)$ & $1.8 \mathrm{Bb}(3.6)$ & $12.9 \mathrm{Ab}(15.3)$ \\
\hline
\end{tabular}

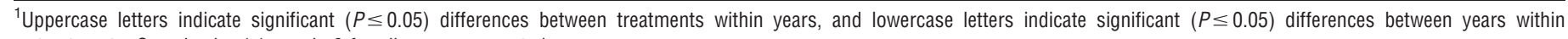
treatments. Sample size $(n)$ equals 6 for all means presented. 
Table 2. Mean (SD) organic carbon, root biomass, random roughness, soil moisture, bulk density, and aggregate stability before the dry rainfall simulation run and soil moisture, bulk density and aggregate stability before the wet rainfall simulation run by year and treatment. ${ }^{1}$

\begin{tabular}{|c|c|c|c|c|c|c|c|c|c|}
\hline & \multicolumn{3}{|c|}{1990} & \multicolumn{3}{|c|}{1991} & \multicolumn{3}{|c|}{1992} \\
\hline & A & D & C & $A$ & D & C & $A$ & D & C \\
\hline \multicolumn{10}{|l|}{ Dry run } \\
\hline Soil moisture (\%), $n=24$ & $\begin{array}{r}1.9 \mathrm{Ab} \\
(0.52)\end{array}$ & $\begin{array}{r}1.8 \mathrm{Ab} \\
(0.51)\end{array}$ & $\begin{array}{r}1.8 \mathrm{Ab} \\
(0.45)\end{array}$ & $\begin{array}{c}1.9 \mathrm{Ab} \\
(0.64)\end{array}$ & $\begin{array}{r}2.2 \mathrm{Ab} \\
(0.58)\end{array}$ & $\begin{array}{r}2.2 \mathrm{Ab} \\
(0.69)\end{array}$ & $\begin{array}{r}9.7 \mathrm{Aa} \\
(4.4)\end{array}$ & $\begin{array}{r}7.8 \mathrm{Ba} \\
(4.3)\end{array}$ & $\begin{array}{r}8.9 \mathrm{Aa} \\
(4.5)\end{array}$ \\
\hline Bulk density $\left(\mathrm{g} \cdot \mathrm{cm}^{-3}\right), n=24$ & $\begin{array}{r}1.23 \mathrm{Aa} \\
(0.10)\end{array}$ & $\begin{array}{r}1.20 \mathrm{Aa} \\
(0.13)\end{array}$ & $\begin{array}{r}1.25 \mathrm{Aa} \\
(0.09)\end{array}$ & $\begin{array}{r}1.17 \mathrm{Aa} \\
(0.11)\end{array}$ & $\begin{array}{r}1.19 \mathrm{Aa} \\
(0.09)\end{array}$ & $\begin{array}{r}1.22 \mathrm{Aa} \\
(0.12)\end{array}$ & $\begin{array}{r}1.21 \mathrm{Aa} \\
(0.13)\end{array}$ & $\begin{array}{r}1.12 \mathrm{Ba} \\
(0.12)\end{array}$ & $\begin{array}{r}1.22 \mathrm{Aa} \\
(0.12)\end{array}$ \\
\hline Aggregate stability (\%), $n=48$ & $\begin{array}{c}59.1 \mathrm{Ba} \\
(9.7)\end{array}$ & $\begin{array}{r}58.9 \mathrm{Ba} \\
(10.7)\end{array}$ & $\begin{array}{r}64.5 \mathrm{Aa} \\
(13.1)\end{array}$ & $\begin{array}{c}65.1 \text { Aba } \\
(13.7)\end{array}$ & $\begin{array}{c}58.6 \mathrm{Ba} \\
(9.6)\end{array}$ & $\begin{array}{r}65.5 \mathrm{Aa} \\
(13.5)\end{array}$ & $\begin{array}{r}40.0 \mathrm{Ba} \\
(13.2)\end{array}$ & $\begin{array}{r}52.1 \mathrm{Ab} \\
(14.6)\end{array}$ & $\begin{array}{r}50.9 \mathrm{Ab} \\
(14.5)\end{array}$ \\
\hline Organic carbon $(\%), n=24$ & $\begin{array}{r}1.62 \mathrm{Aa} \\
(0.58)\end{array}$ & $\begin{array}{r}1.01 \mathrm{Ba} \\
(0.28)\end{array}$ & $\begin{array}{c}1.29 \mathrm{ABa} \\
(0.21)\end{array}$ & $\begin{array}{r}1.38 \mathrm{Aa} \\
(0.32)\end{array}$ & $\begin{array}{r}1.22 \mathrm{Aa} \\
(0.38)\end{array}$ & $\begin{array}{r}1.48 \mathrm{Aa} \\
(0.21)\end{array}$ & $\begin{array}{r}0.75 \mathrm{Bb} \\
(0.22)\end{array}$ & $\begin{array}{r}1.11 \mathrm{Aa} \\
(0.22)\end{array}$ & $\begin{array}{c}0.96 \mathrm{ABb} \\
(0.24)\end{array}$ \\
\hline Random roughness $(\mathrm{mm}), n=60$ & $\begin{array}{r}1.10 \mathrm{Aa} \\
(0.07)\end{array}$ & $\begin{array}{r}1.45 \mathrm{Aa} \\
(0.63)\end{array}$ & $\begin{array}{r}1.04 \mathrm{Aa} \\
(0.23)\end{array}$ & $\begin{array}{r}1.46 \mathrm{Aa} \\
(0.28)\end{array}$ & $\begin{array}{r}1.61 \mathrm{Aa} \\
(0.78)\end{array}$ & $\begin{array}{r}1.43 \mathrm{Aa} \\
(0.60)\end{array}$ & $\begin{array}{c}1.52 \mathrm{ABa} \\
(0.60)\end{array}$ & $\begin{array}{r}1.83 \mathrm{Aa} \\
(0.96)\end{array}$ & $\begin{array}{r}1.06 \mathrm{Ba} \\
(0.09)\end{array}$ \\
\hline Root biomass $\left(\mathrm{g} \cdot \mathrm{cm}^{-3}\right), n=24$ & $\begin{array}{c}0.00141 \mathrm{ABa} \\
(0.00048)\end{array}$ & $\begin{array}{r}0.00070 \mathrm{Ba} \\
(0.00080)\end{array}$ & $\begin{array}{c}0.00274 \mathrm{Aa} \\
(0.0032)\end{array}$ & $\begin{array}{r}0.00132 \mathrm{Aa} \\
(0.00092)\end{array}$ & $\begin{array}{r}0.00066 \mathrm{Ba} \\
(0.00059)\end{array}$ & $\begin{array}{r}0.00142 \mathrm{Aa} \\
(0.00089)\end{array}$ & $\begin{array}{r}0.00153 \mathrm{Aa} \\
(0.00056)\end{array}$ & $\begin{array}{r}0.00114 \mathrm{Aa} \\
(0.00094)\end{array}$ & $\begin{array}{r}0.00080 \mathrm{Aa} \\
(0.00065)\end{array}$ \\
\hline \multicolumn{10}{|l|}{ Wet run } \\
\hline Soil moisture $(\%), n=24$ & $\begin{array}{c}25.8 \mathrm{Aa} \\
(3.0)\end{array}$ & $\begin{array}{c}16.9 \mathrm{Bb} \\
(4.1)\end{array}$ & $\begin{array}{r}26.5 \mathrm{Aa} \\
(2.9)\end{array}$ & $\begin{array}{c}27.4 \mathrm{Aa} \\
(3.1)\end{array}$ & $\begin{array}{c}23.8 \mathrm{Ba} \\
(3.5)\end{array}$ & $\begin{array}{c}26.5 \mathrm{Aa} \\
(3.8)\end{array}$ & $\begin{array}{c}22.3 \mathrm{Ab} \\
(3.2)\end{array}$ & $\begin{array}{c}22.3 \mathrm{Aa} \\
(3.7)\end{array}$ & $\begin{array}{c}20.7 \mathrm{Ab} \\
(3.9)\end{array}$ \\
\hline Bulk density $\left(\mathrm{g} \cdot \mathrm{cm}^{-3}\right), n=24$ & $\begin{array}{r}1.14 \mathrm{Ab} \\
(0.19)\end{array}$ & $\begin{array}{r}1.10 \mathrm{Aa} \\
(0.14)\end{array}$ & $\begin{array}{r}1.16 \mathrm{Ab} \\
(0.11)\end{array}$ & $\begin{array}{r}1.14 \mathrm{Ab} \\
(0.14)\end{array}$ & $\begin{array}{r}1.06 \mathrm{Ba} \\
(0.12)\end{array}$ & $\begin{array}{r}1.16 \mathrm{Ab} \\
(0.10)\end{array}$ & $\begin{array}{r}1.28 \mathrm{Aa} \\
(0.17)\end{array}$ & $\begin{array}{r}1.06 \mathrm{Ba} \\
(0.17)\end{array}$ & $\begin{array}{r}1.30 \mathrm{Aa} \\
(0.14)\end{array}$ \\
\hline Aggregate stability $(\%), n=48$ & $\begin{array}{c}27.2 \mathrm{Bb} \\
(7.8)\end{array}$ & $\begin{array}{r}44.8 \mathrm{Aa} \\
(17.3)\end{array}$ & $\begin{array}{r}25.1 \mathrm{Bb} \\
(10.3)\end{array}$ & $\begin{array}{r}37.3 \mathrm{Aa} \\
(12.5)\end{array}$ & $\begin{array}{r}41.4 \mathrm{Aa} \\
(15.6)\end{array}$ & $\begin{array}{r}37.8 \mathrm{Aa} \\
(18.1)\end{array}$ & $\begin{array}{r}30.5 \mathrm{Bb} \\
(13.4)\end{array}$ & $\begin{array}{r}43.6 \mathrm{Aa} \\
(16.1)\end{array}$ & $\begin{array}{r}34.4 \mathrm{Ba} \\
(14.0)\end{array}$ \\
\hline
\end{tabular}

${ }^{1}$ Treatments: A indicates Amazon-drill; D, disk-chain; C, control. Uppercase letters indicate significant $(P \leq 0.05)$ differences between treatments within years, and lowercase letters indicate significant $(P \leq 0.05)$ differences between years within treatments.

It would be reasonable to expect that antecedent soil moisture levels would have less effect on aggregate stability under wet soil conditions.

Organic carbon content was generally lowest for the diskchain treatment, and the Amazon-drill and control showed significant drops in organic carbon to near disk-chain levels during the third summer after treatment (Table 2). Random surface roughness was higher in both the Amazon-drill and disk-chain treatments compared with the control (Table 2), but the differences were not statistically significant. By visual inspection, the disk-chain did appear to significantly modify the surface microtopography. However, the resultant furrowing effect was oriented across the plot and parallel to the pointframe transects and, therefore, was not adequately quantified. No significant annual trends in random surface roughness were found under any treatment or the control. The soil-mixing effect of the disk-chain treatment caused a reduction in nearsurface root biomass during the first 2 growing seasons after treatment (Table 2). By the third summer, no differences in root biomass were detected.

Soil particle-size variation was minimal between treatments within and between years. Sand and silt contents throughout the study ranged $36 \%-44 \%$ and $45 \%-55 \%$ across treatments, respectively. Differences in sand and silt contents between treatments and years were insignificant. Clay content ranged from $9 \%$ to $14 \%$ across all treatments throughout the study and was slightly higher for the disk-chain treatment each year. The elevated clay content on the disk-chain treatment likely resulted from upward transfer of clay content during disking.
The mechanical seeding treatments used in this study were generally unsuccessful at establishing both native and introduced perennial plants. The disk-chain treatment did have a significantly higher canopy cover of crested wheatgrass plants during the first 2 growing seasons compared with the Amazondrill or the control, but the percent cover was low and became insignificant by the end of the study (Table 3). By the third growing season, the Amazon-drill and control had higher canopy covers of sandberg bluegrass, a native perennial grass, than did the disk-chain treatment. Because of the lack of seeding success, the canopy for all treatments, including the control, was dominated by cheatgrass.

There was a significant downward trend in the percentage of bare ground for all treatments and the control between the beginning (postburn) and end of the study (Table 3). Bare ground was particularly high for the disk-chain treatment at the start of the study $(97 \%)$ because of the "plowing" effect of the implement and was still significantly higher than the control at the end of the study $(37.5 \%)$. These trends were mirroropposites of observed trends for percentage of surface litter cover (Table 3). Litter cover was lowest for the disk-chain and significantly increased in all treatments through the second growing season. Litter cover for the disk-chain continued to significantly increase through the third growing season where it finally reached levels equal to the control and Amazon drill. All treatments had significant trends of increasing vegetation and litter biomass over the course of the study (Table 3). Litter biomass was significantly lower for the disk-chain treatment compared with the control during the first growing season with 
Table 3. Mean canopy cover, ground cover, and biomass by year and treatment. ${ }^{1}$

\begin{tabular}{|c|c|c|c|c|c|c|c|c|c|}
\hline & \multicolumn{3}{|c|}{1990} & \multicolumn{3}{|c|}{1991} & \multicolumn{3}{|c|}{1992} \\
\hline & A & D & C & A & D & C & A & D & C \\
\hline \multicolumn{10}{|l|}{ Canopy cover (\%) } \\
\hline Crested wheatgrass & $0.8 \mathrm{Ba}(0.9)$ & $2.3 \mathrm{Ab}(1.4)$ & $0.0 \mathrm{Ba}(0.0)$ & 1.6 Ba (1.5) & $4.4 \mathrm{Aa} \mathrm{(2.5)}$ & $0.0 \mathrm{Ba}(0.0)$ & $1.40 \mathrm{Aa}(0.8)$ & $0.5 \mathrm{ABb}(0.9)$ & $0.0 \mathrm{Ba}(0.0)$ \\
\hline Cheatgrass & 37.9 Ab (9.8) & 17.7 Bb (12.4) & $35.1 \mathrm{Ab}(16.1)$ & $54.9 \mathrm{Ba}(7.0)$ & $36.0 \mathrm{Ca}(7.2)$ & $61.7 \mathrm{Aa}(5.1)$ & $30.3 \mathrm{Ab}(17.4)$ & 29.1 Aa (8.4) & $39.6 \mathrm{Ab}(10.5)$ \\
\hline Sandberg bluegrass & $4.1 \mathrm{Ab}(5.3)$ & 0.1 Aab (0.3) & 4.3 Аа (5.1) & $3.3 \mathrm{Ab}(2.3)$ & $3.1 \mathrm{Aa}(3.8)$ & $3.2 \mathrm{Aa}(3.1)$ & 15.3 Аа (11.0) & $3.7 \mathrm{Ba}(6.0)$ & $9.6 \mathrm{ABa}(10.0)$ \\
\hline Forb & $1.5 \mathrm{ABa}(0.7)$ & $0.8 \mathrm{Aa}(0.8)$ & $1.8 \mathrm{Aa}(0.6)$ & $0.7 \mathrm{Ba}(1.0)$ & $2.3 \mathrm{Aa}(1.6)$ & $0.2 \mathrm{Bb}(0.3)$ & $1.5 \mathrm{Aa}(3.0)$ & $2.3 \mathrm{Aa}(3.5)$ & 1.1 Aab (1.6) \\
\hline Grass & $43.2 \mathrm{Ab}(6.9)$ & 20.2 Bc (12.0) & 39.7 Ac (11.0) & $60.5 \mathrm{Aa}(7.1)$ & $43.8 \mathrm{Ba}(8.0)$ & 65.4 Aa (7.2) & $48.0 \mathrm{Ab}(9.8)$ & $33.3 \mathrm{Bb}(11.9)$ & $49.8 \mathrm{Ab}(4.7)$ \\
\hline Total & $45.2 \mathrm{Ab}(6.8)$ & $27.7 \mathrm{Bc}(6.3)$ & 41.7 Ac (11.1) & $63.2 \mathrm{Aa}(5.0)$ & $50.2 \mathrm{Ba}(4.3)$ & $66.3 \mathrm{Aa}(6.7)$ & $51.0 \mathrm{Ab}(9.4)$ & $36.8 \mathrm{Bb}(10.6)$ & $54.1 \mathrm{Ab}(4.7)$ \\
\hline \multicolumn{10}{|l|}{ Ground cover (\%) } \\
\hline Bare ground & 71.6 Ba (14.2) & $97.2 \mathrm{Aa}(2.0)$ & $57.5 \mathrm{Ca} \mathrm{(13.6)}$ & $30.2 \mathrm{Bb}(7.6)$ & $65.5 \mathrm{Ab}(5.5)$ & $22.6 \mathrm{Cb}(3.4)$ & $33.4 \mathrm{ABb}(16.5)$ & 37.5 Ac (13.0) & $21.7 \mathrm{Bb}(7.6)$ \\
\hline Litter & $28.2 \mathrm{Bb}(14.0)$ & 2.4 Cc (1.5) & 42.4 Ab (13.7) & $69.0 \mathrm{Ba}(6.7)$ & $33.6 \mathrm{Cb}(5.5)$ & $76.7 \mathrm{Aa}(3.6)$ & $63.8 \mathrm{Aa} \mathrm{(17.3)}$ & $60.7 \mathrm{Aa}(13.9)$ & 75.1 Aa (6.8) \\
\hline \multicolumn{10}{|l|}{ Biomass $\left(\mathrm{kg} \cdot \mathrm{ha}^{-1}\right)$} \\
\hline Vegetation & $952 \mathrm{Ab}(249)$ & 981 Аа (691) & 579 Ac (141) & $1141 \mathrm{ABb}(96)$ & $1407 \mathrm{Aa} \mathrm{(394)}$ & $983 \mathrm{Bb}(156)$ & 1976 Аа (531) & $1772 \mathrm{Aa} \mathrm{(400)}$ & $1503 \mathrm{Aa} \mathrm{(119)}$ \\
\hline Litter & $171 \mathrm{ABb}(140)$ & 21 Bc (42) & $329 \mathrm{Aa}(286)$ & $317 \mathrm{Ab}(155)$ & $425 \mathrm{Ab}(138)$ & 270 Аа (163) & 793 Аа (495) & 783 Аа (349) & $570 \mathrm{Aa}(198)$ \\
\hline
\end{tabular}

no significant differences thereafter. Vegetation biomass increased each year for all treatments and was similar across treatments within each growing season.

Observed trends in hydrologic and erosion responses between treatments and across years for both dry and wet antecedent soil-moisture conditions were better correlated with variations in canopy and ground cover than with soil properties. Litter cover had the highest correlation coefficients across all treatments and years with all hydrologic and erosion variables, followed closely by bare ground (Table 4). Correlation coefficients were consistently higher for the wet soil conditions compared with dry soil. This is a common observation and is why soil wetting is commonly used in treatment-comparison studies to reduce background variability in soil properties between rainfall simulation plots.

\section{DISCUSSION}

The hydrologic and erosional impacts of burning and mechanical-seeding treatments and the persistence of impacts were greater for the disk chain than the Amazon drill. The diskchain treatment significantly reduced infiltration (Fig. 2) and increased runoff (Fig. 1) and sediment yield (Table 1) through 2 summers posttreatment under dry and wet antecedent soil- moisture conditions. Reduced infiltration and increased runoff associated with the Amazon-drill treatment were restricted to the summer following the treatment. Brown et al. (1985) reported similar recovery periods for infiltration and sediment yield on Wyoming big sagebrush sites following disk-plow and seed, spray and seed, and prescribed burn and seed applications with crested wheatgrass. The study reported initial reduced infiltration following all 3 treatments and increased sediment yield on the plow and seed, and burn and seed, treatments. Infiltration and sediment yield from all treatments was nearing control levels 3 years posttreatment. Other disk-plowing and seeding studies in rangeland systems have reported that reduced infiltration and sediment yield posttreatment require 3 to 6 years to return to control levels (Gifford and Skau 1967; Gifford 1982). These studies all suggest the degree of disturbance is the key indicator for increased runoff and sediment yield posttreatment. In this study, the continued high sediment:runoff ratio (Fig. 3) on the disk-chain treatment 2 summers posttreatment and the concurrent reduction in sediment yield (Table 1) and runoff:rainfall (Fig. 1) indicate erosion recovery was primarily due to increased infiltration (Fig. 2) rather than decreased erodibility. The more rapid improvement in hydrologic conditions on Amazon-drill plots was due to lower impacts of the equipment on infiltration processes. This is further supported by the significantly higher

Table 4. Correlation coefficients $(r)$ of final infiltration rate, runoff:rainfall ratio, cumulative sediment yield, and sediment:runoff ratio with litter ground cover, bare ground, canopy cover, and canopy cover of cheatgrass (BRTE). All correlation coefficients are significant at the $P \leq 0.05$ level and are presented for both the dry and wet rainfall simulation runs.

\begin{tabular}{|c|c|c|c|c|c|c|c|c|}
\hline & \multicolumn{4}{|c|}{ Dry run } & \multicolumn{4}{|c|}{ Wet run } \\
\hline & $\begin{array}{l}\text { Litter cover } \\
\quad(\%)\end{array}$ & $\begin{array}{c}\text { Bare ground } \\
(\%)\end{array}$ & $\begin{array}{c}\text { Canopy } \\
\text { cover (\%) }\end{array}$ & $\begin{array}{c}\text { BRTE canopy } \\
\text { cover (\%) }\end{array}$ & $\begin{array}{l}\text { Litter cover } \\
\quad(\%)\end{array}$ & $\begin{array}{l}\text { Bare ground } \\
(\%)\end{array}$ & $\begin{array}{l}\text { Canopy } \\
\text { cover }(\%)\end{array}$ & $\begin{array}{l}\text { BRTE canopy } \\
\text { cover }(\%)\end{array}$ \\
\hline Final infiltration rate $\left(\mathrm{mm} \cdot \mathrm{h}^{-1}\right)$ & 0.79 & -0.78 & 0.67 & 0.62 & 0.87 & -0.86 & 0.76 & 0.69 \\
\hline Runoff:rainfall ratio $\left(\mathrm{mm} \cdot \mathrm{mm}^{-1}\right)$ & -0.80 & 0.79 & -0.59 & -0.47 & -0.90 & 0.90 & -0.71 & -0.60 \\
\hline Cumulative sediment yield $\left(\mathrm{kg} \cdot \mathrm{ha}^{-1}\right)$ & -0.67 & 0.66 & -0.46 & -0.34 & -0.73 & 0.72 & -0.53 & -0.41 \\
\hline Sediment:runoff ratio $\left(\mathrm{kg} \cdot \mathrm{ha}^{-1} \cdot \mathrm{mm}^{-1}\right)$ & -0.60 & 0.59 & -0.36 & -0.28 & -0.64 & 0.64 & -0.43 & -0.36 \\
\hline
\end{tabular}


final infiltration rate (Fig. 2) and lower runoff:rainfall ratio (Fig. 1) for the Amazon drill vs. disk chain 2 summers following treatment.

The hydrologic impact and recovery of the mechanical seeding treatments do not appear to be explained by any of the measured surface soil properties. Annual variations and treatment differences in soil surface bulk density, organic carbon, and root biomass provide little insight into observed hydrologic and erosion responses. Aggregate stability and random roughness results not only do not explain differences in runoff and erosion but also confound interpretation of hydrologic and erosion results. Higher aggregate stability and random roughness values for the disk-chain treatment would indicate that it should have the lowest runoff and erosion responses. Kincaid and Williams (1966) analyzed rainfall effects on surface soil characteristics following rangeland treatments and determined vegetative cover exerted greater influence on runoff generation than treatment influenced surface soil properties. Bedunah and Sosebee (1985) found infiltration following mechanical treatments on heavily infested mesquite (Prosopis glandulosa Torr.) sites was controlled by interactions between soil and plant variables. Wilcox et al. (1988) further identified strongly positive correlations between vegetative cover and biomass and rangeland infiltration. Blackburn et al. (1992) reported vegetation and its growth form were the primary factors influencing surface soil properties that control rangeland infiltration. Blackburn et al. (1992) further demonstrated that normal fluctuations in climate and vegetation significantly influenced surface soil properties. The results from this study and from literature suggest influences of soil surface properties on rangeland infiltration are largely dependent on the vegetation characteristics of the respective site and normal variations in climate. Therefore, any treatment effects on infiltration caused by changes to surface soil properties in this study are likely masked by treatment effects on vegetation establishment and temporal variation in surface soil conditions.

The hydrologic and erosion impacts of the burning and mechanical-seeding equipment used in this study can be explained by the amount of bare soil that each treatment produced and the rate at which litter cover increased to reduce the amount of bare soil to below critical levels. Increased bare soil results in increased exposure to surface soil sealing, raindrop impact, and the erosive force of overland flow. So as percentage of surface-litter ground cover goes up and percentage of bare ground goes down, infiltration increases, and runoff and erosion decrease. Gifford (1985) reviewed extensive literature and concluded that percentage of bare ground should be maintained below a critical threshold of $40 \%-50 \%$ to adequately protect a site and maintain soil and hydrologic stability. The plowing effect of the disk-chain treatment combined with pretreatment burning resulted in $97 \%$ exposed bare soil. Subsequently, 3 growing seasons were required to rebuild the litter cover sufficiently to reduce the percentage of bare ground to below the critical $40 \%$ level. Such exposure of bare soil is why Gifford and Skau (1967) recommended that plowing soil for revegetation purposes should be avoided in areas with marginal or low probability of a successful seeding. The burned Amazon-drill treatment had a moderate hydrologic impact compared with the burned disk- chain treatment because it initially produced only $72 \%$ bare soil and was able to reduce the amount of exposed bare soil to below the critical level of $40 \%$ by the end of the second growing season. The "plowing" effect of the disk-chain likely made it more difficult for native species to survive. The diskchain was the most successful at controlling cheatgrass by burying cheatgrass seeds and reducing the amount of seed available for germination the following year. This resulted in the disk-chain treatment having the lowest cheatgrass canopy cover and, thus, the lowest total canopy cover, throughout the duration of the study (Table 3).

\section{MANAGEMENT IMPLICATIONS}

The majority of the hydrologic and erosion impacts created by burning and the Amazon-drill and disk-chain treatments were insignificant after 2 to 3 years following treatment application. The significant annual recovery in hydrologic response was not echoed in the measured soil-surface properties as hypothesized. Annual variations and treatment differences in surface-soil bulk density, aggregate stability, and random roughness were not of the magnitude to indicate that observed hydrologic recovery was a consequence of trends in these surface soil properties. Although soil properties undoubtedly influence hydrologic and erosion responses, interpretations of treatment-induced variations in surface soil responses are confounded by considerable seasonal variation that is difficult to extract from the effects of the treatments. Such confounding results are common in the literature (Gifford 1975; Gifford 1985; Blackburn et al. 1992). More study is needed on interactions between temporally varying surface soil properties and treatment induced soil disturbances and their subsequent impacts on hydrologic and erosion responses.

The patterns of hydrologic response through time to treatment impacts observed in this study are most easily interpreted as a response to vegetation and surface cover dynamics. The burning and disk-chain treatment created the largest and most long-lasting hydrologic impact by removing virtually all the surface soil cover. The rate of recovery in hydrologic response for each treatment was controlled by the rate at which total surface cover (litter) increased until the amount of bare soil was reduced below critical levels. Because the disk-chain treatment created the greatest initial reduction in surface cover, it, therefore, took additional growing seasons to produce sufficient litter to provide adequate ground cover.

The relationship between hydrologic recovery and vegetation dynamics observed in this study suggests that revegetation projects should be evaluated in terms of their efficiency in obtaining the desired plant community balanced against the consequences of creating a window in time of elevated runoff and erosion risk. In this study, the initial goal of using seeding treatments to establish perennial grass species was a failure. However, cheatgrass did provide rapid accumulation of biomass and surface litter cover after the first year, which enhanced hydrologic recovery of the site. The window of elevated erosion risk was short, in large part, because of cheatgrass rapidly occupies disturbed treatments and rapidly produces large amounts of litter biomass. Unsuccessful seed- 
ings, in areas not dominated by cheatgrass, could have much broader windows of high runoff and erosion risk.

\section{ACKNOWLEDGMENT}

The mechanical seeding treatments were applied by the USDA-FS, Provo Shrub Sciences Laboratory.

\section{LITERATURE CITED}

Bedunah, D. J., and R. E. Sosebee. 1985. Influence of site manipulations on infiltration rates of a depleted west Texas range site. Journal of Range Management 38:200-205.

BILlings, W. D. 1990. Bromus tectorum, a biotic cause of ecosystem impoverishment in the Great Basin. In: G. M. Woodwell [ED.]. The earth in transition: patterns and processes of biotic impoverishment. New York, NY: Cambridge University Press. p. 300-322.

BıLıINGS, W. D. 1994. Ecological impacts of cheatgrass and resultant fire on ecosystems in the western Great Basin. In: S. B. Monsen and S. G. Kitchen [EDS.]. Proceedings of Ecology and Management of Annual Rangelands. Ogden, UT: US Department of Agriculture, Forest Service, Intermountain Research Station General Technical Report INT-GTR-313. p. 22-30.

BLACKBURN, W. H. 1983. Influence of brush control on hydrologic characteristics of range watersheds. In: Proceedings of Brush Management Symposium. Denver, C0: Society for Range Management. p. 73-88.

Blackburn, W. H., F. B. Pierson, C. L. Hanson, T. L. Thurow, and A. L. Hanson. 1992. The spatial and temporal influence of vegetation on surface soil factors in semiarid rangelands. Transactions of the ASAE 35:479-486.

BLACKBURN, W. H., AND C. M. SkAu. 1974. Infiltration rates and sediment production of selected plant communities in Nevada. Journal of Range Management 27:476-480.

Bonta, J. V., and V. C. Goyal. 2001. Modified drop-box weir for monitoring watershed flows under extreme approach channel conditions. Transactions of the ASAE 44:1581-1591.

Brown, J. C., R. A. Evans, and J. A. Young. 1985. Effects of sagebrush control methods and seeding on runoff and erosion. Journal of Range Management 38:195-199.

Canadian Ministers of Agriculture. 1985. Evaluation Report 421 of the Amazon, MT 375 no-till grain drill. Humboldt, SK: Prairie Agriculture Institute, Ministers of Agriculture, Alberta, Canada. $10 \mathrm{p}$.

CLARY, W. P. 1989. Revegetation by land imprinter and rangeland drill. Ogden, UT: US Department of Agriculture, Forest Service, Intermountain Research Station Research Paper INT-397. 6 p.

Evans, R. A., And J. A. Young. 1978. Effectiveness of rehabilitation practices following wildfire in a degraded big sagebrush-downy brome community. Journal of Range Management 31:185-188.

Evans, R. A., and J. A. Young. 1984. Microsite requirements for downy brome (Bromus tectorum) infestation and control on sagebrush rangelands. Weed Science 32:13-17.

Gee, G. W., and J. W. Bauder. 1986. Particle-size analysis. In: A. Klute [ed.]. Methods of soil analysis: Physical and mineralogical methods. Madison, Wl: Soil Science Society of America Agronomy Series No. 9 (Part I). p. 383-411.

GiFFord, G. F. 1975. Beneficial and detrimental effects of range improvement practices on runoff and erosion. In: Proceedings of Watershed Management Symposium. New York, NY: American Society of Civil Engineers. p. 216-248.

GIFFORD, G. F. 1982. A long-term infiltrometer study in southern Idaho. Journal of Hydrology 58:367-374.

GIFFORD, G. F. 1985. Cover allocation in rangeland watershed management (a review). In: E. B. Jones and T. J. Ward [EDs.]. Proceedings of Watershed Management in the Eighties. New York, NY: American Society of Civil Engineers. p. 23-31.

GifFord, G. F., AND C. M. Skau. 1967. Influence of various rangeland cultural treatments on runoff and sediment production from the big sagebrush type,
Eastgate Basin, Nevada. In: M. Francisco [ED.]. Proceedings of the 3rd annual American Water Resources Conference, Series 3. Urbana, IL: American Water Resources Association. p. 137-148.

Hull, A. C., JR., and G. Stewart. 1948. Replacing cheatgrass by reseeding with perennial grass on southern Idaho ranges. American Society of Agronomy Journal 40:694-703.

Hutten, N. C., and G. F. Gifford. 1988. Some hydrologic impacts of plowing rangeland soil. Water Resources Bulletin 24:175-181.

Kemper, W. D., and R. C. Rosenau. 1986. Aggregate stability and size distribution. In: A. Klute [ED.]. Methods of soil analysis: Physical and mineralogical methods. 2nd ed. Madison, WI: Soil Science Society of America Agronomy Series No. 9 (Part I). p. 424-442.

Kincaid, D. R., And G. Williams. 1966. Rainfall effects on soil surface characteristics following rangeland improvement treatments. Journal of Rangeland Management 19:346-351.

KNICK, S. T., AND J. T. RotenberRy. 1997. Landscape characteristics of disturbed shrubsteppe habitats in southwestern Idaho (USA). Landscape Ecology 12:287-297.

Masters, R. A., and R. L. Sheley. 2001. Principles and practices for management of rangeland invasive plants. Journal of Range Management 54: 502-517.

Mattise, S. N., and G. Scholten. 1994. Mechanical control of undesirable annuals on the Boise Front, Idaho. In: S. B. Monsen and S. G. Kitchen [Eds.]. Proceedings of Ecology and Management of Annual Rangelands. Ogden, UT: US Department of Agriculture, Forest Service, Intermountain Research Station General Technical Report INT-GTR-313. p. 190-193.

Mclver, J., And L. StaRR. 2001. Restoration of degraded lands in the interior Columbia River basin: passive vs. active approaches. Forest Ecology and Management 153:15-28.

National Research Council. 1994. Rangeland health: new methods to classify, inventory, and monitor rangelands. Washington, DC: Committee on rangeland classification, Board of Agriculture, National Academy Press. $200 \mathrm{p}$.

Nelson, D. W., and L. E. Sommers. 1982. Total carbon, organic carbon, and organic matter. In: A. L. Page [ed.]. Methods of Soil Analysis: Chemical and microbiological properties. Madison, WI: Soil Science Society of America Agronomy Series No. 9 (Part II). p. 539-579.

NoE, H. R. 1991. Soil survey of Elmore County area, Idaho, parts of Elmore, Owyhee, and Ada counties. Boise, ID: US Department of Agriculture, Soil Conservation Service. 500 p.

Ott, J. E., E. D. Mcarthur, and B. A. Roundy. 2003. Vegetation of chained and nonchained seedings after wildfire in Utah. Journal of Range Management 56:81-91.

Owenby, J. R., AND D. S. Ezell. 1992. Monthly station normals of temperature, precipitation, and heating and cooling degree-days 1961-1990: Idaho. Asheville, NC: National Oceanic and Atmospheric Administration, US Department of Commerce, National Climatic Data Center Climatography of the US No. $81.12 \mathrm{p}$.

Pellant, M. 1990. The cheatgrass-wildfire cycle-are there any solutions? In: E. D. McArthur, E. M. Romney, S. D. Smith, and P. T. Tueller [Eds.]. Proceedings of Symposium on Cheatgrass Invasion, Shrub Die-off, and Other Aspects of Shrub Biology and Management. Ogden, UT: US Department of Agriculture, Forest Service, Intermountain Research Station General Technical Report INT-GTR-276. p. 11-18.

Pellant, M. 1994. History and applications of the intermountain greenstripping program. In: S. B. Monsen and S. G. Kitchen [EDS.]. Proceedings of Ecology and Management of Annual Rangelands. Ogden, UT: US Department of Agriculture, Forest Service, Intermountain Research Station General Technical Report INT-GTR-313. p. 63-68.

SAS [Computer Program]. 2001. SAS/STAT User's Guide. Release 8.2. Cary, NC: SAS Institute Inc. $1028 \mathrm{p}$.

SWAnson, N. P. 1965. Rotating-boom rainfall simulator. Transactions of the ASAE 8:71-72.

Tromble, J. M. 1976. Semiarid rangeland treatment and surface runoff. Journal of Range Management 29:251-255. 
[USDA-NRCS] US Department of Agriculture, National Resource Conservation SERvice. 2007. Official soil series descriptions. Available at: http://soils.usda. gov/technical/classification/osd/index.html. Accessed 7 June 2007.

[USDI-BLM] US Department of the Interior, Bureau of Land Management. 1999. Out of ashes, an opportunity. Boise, ID: Bureau of Land Management, National Office of Fire and Aviation. $33 p$.

Whisenant, S. G. 1990. Changing fire frequencies on Idaho's Snake River Plains: ecological and management implications. In: Proceedings of Symposium on Cheatgrass Invasion, Shrub Die-off and Other Aspects of Shrub Biology and Management. Ogden, UT: US Department of Agriculture, Forest Service,
Intermountain Research Station General Technical Report INT-GTR-276. p. 4-10.

Wiedemann, H. T., ANd B. T. Cross. 1985. Influence of pulling configuration on draft of disk-chains. Transactions of the ASAE 28:79-82.

Wiedemann, H. T., and B. T. Cross. 2000. Disk chain effects on seeded grass establishment. Journal of Range Management 53:62-67.

Wilcox, B. P., M. K. Wood, And J. H. Tromble. 1988. Factors influencing infiltrability of semiarid mountain slopes. Journal of Range Management 41:197-206.

Young, J. A., and R. A. Evans. 1978. Population dynamics after wildfires in sagebrush grasslands. Journal of Range Management 31:283-289. 